\title{
Historical and human dimensions of climate variability and water resource constraint in the Senegal River Valley
}

\author{
John Magistro ${ }^{1, *}$, Medou Lo ${ }^{2}$ \\ ${ }^{1}$ International Development Enterprises, 10403 West Colfax Avenue, Suite 500, Lakewood, \\ Colorado 80215, USA \\ ${ }^{2}$ Centre de Suivi Ecologique, Rue Léon Go ntran Damas, Fann Résidence, BP15532 Dakar, Senegal
}

\begin{abstract}
This paper provides a case study from the northern Senegal wetlands documenting trends in inter-annual and seasonal climate variability during the past century as well as human vulnerability and adaptation to anomalous climate events. A secular decline in precipitation during the past 3 decades has resulted in the construction of 2 dams on the Senegal River in the 1980s and an interstate river basin development strategy to develop hydroelectricity, irrigation farming, and a navigable waterway. Current agro-ecological production systems dependent on a seasonal riparian flood cycle could be curtailed in trying to meet these development objectives. Two hydrological time flow series illustrating the importance of inter-annual and seasonal climate variability for the region are used to weigh the costs and benefits of competing water use scenarios for end users.
\end{abstract}

KEY WORDS: Adaptation · Climate variability · Human dimensions - Senegal River Valley · Dams · Water resources

Resale or republication not permitted without written consent of the publisher

\section{INTRODUCTION}

In recent years, research on global climate change impacts has been enhanced by complex computer models that simulate the dynamic biophysical state of ocean-atmosphere circulation patterns. This scenariodriven 'impact approach' operates from fundamental assumptions about the nature of human adaptation and behavioral response to climate extremes (Smit et al. 1996, p. 8). Human decision-making, however, is rarely reduced to 1 determining variable, such as climate change. Rather, an array of variables, such as economic, technological, social, and institutional processes, interact with climate phenomena to shape the course of human outcomes. Smithers \& Smit (1997, p. 137) note that it is the constellation of non-biophysical factors that must be more appropriately accounted

*E-mail: jmagistro@ideorg.org for in modeling human response to extreme climate events:

\footnotetext{
'Human systems respond not only to environmental conditions but also to economic, technological, institutional, political, and social conditions - and changes in any of these domains are capable of perturbing human systems. The relative importance and role of these potential influences on adaptation and their synergistic effects with climate are not well understood. Estimations of both impacts and human responses would be improved th[r]ough a better accounting of this issue.'
}

This paper provides a historical frame in which to read the sociopolitical and economic context that has shaped human behavior and adaptation to climatic vagaries in one of the largest Sahelian river basins of west Africa - the Senegal River Valley. It is argued that future modeling of adaptation in impact studies should draw from actual empirical observation by taking into account the historical, social, political, and 
economic parameters that intersect with the seasonal and inter-annual dimensions of climate variability. The merit of incorporating a contextual historical understanding of adaptation to the inter-annual and seasonal fluctuations in climate based upon an analogue case study approach was proposed by Glantz (1988), among others. This approach has since gained credibility as a viable research strategy for better understanding human adaptation and societal coping mechanisms under conditions of severe climate stress (Raynor \& Malone 1998).

Furthermore, the empirical case study approach adopted in this paper provides a disaggregation of global spatial and temporal scale that has been strikingly absent in climate change research (Dow 1992). Glantz suggests that such an approach, taking into account the nature of human response to inter-annual and seasonal variability, offers a more relevant assessment of human vulnerabilities in a developing nation context, grounded in present needs rather than future scenario simulations. Recent climate research on variability (Climate Change 45:230-235, 2000), particularly that of Glantz (1992, p. 185), underscores the importance of situating climate change within the context of studies on seasonal and inter-annual climate variability:

In the long term linking climate change issues to climate variability issues will provide the best approach to the development of national and continent-wide strategies to deal with the yet-unknown regional consequences of a yet-unknown global climate change decades in the future.

Drawing from several years of ethnographic field observation in the Senegal River Valley, this paper provides an alternative approach to adaptation research on climate change, focusing on historical and contemporary human response to inter-annual and seasonal climate variability. The Senegal River Valley, representative of much of the west African Sahel, exhibits some of the most extreme climate variability in the world. Water resource constraint, in the form of intermittent drought and seasonal river flooding, has plagued more than 1000000 inhabitants of this region during the course of history. As the result of a dry spell since the 1970s in the middle and lower regions of the basin (Fig. 1), 2 dams have been constructed in the mid-1980s in an attempt to mitigate the adverse impacts of water resource scarcity for agriculture, energy, and navigational purposes. ${ }^{1}$ The end objective of this paper is to illustrate the saliency of inter-annual and seasonal variability in rainfall and river runoff in determining the future management of dam reservoir operations, and thus, critical water supply for farmers and agricultural producers in the basin. At stake is a multi-objective water use strategy to satisfy potentially competing user demands for hydroelectric power generation, irrigation agriculture, and river flood simulation for downstream ecosystem rehabilitation and the maintenance of customary production systems and socioeconomic ways of life. Critical to the future vision

\footnotetext{
${ }^{1}$ Only 1 dam, the Manantali in Mali, has any direct bearing on river hydrology relating to climate variability in this paper. The Diama, in Senegal, is a much smaller dam constructed at the river's mouth for anti-saline intrusion from the ocean and has few repercussions on stream flow relating to climate change scenarios (see Fig. 1).
}

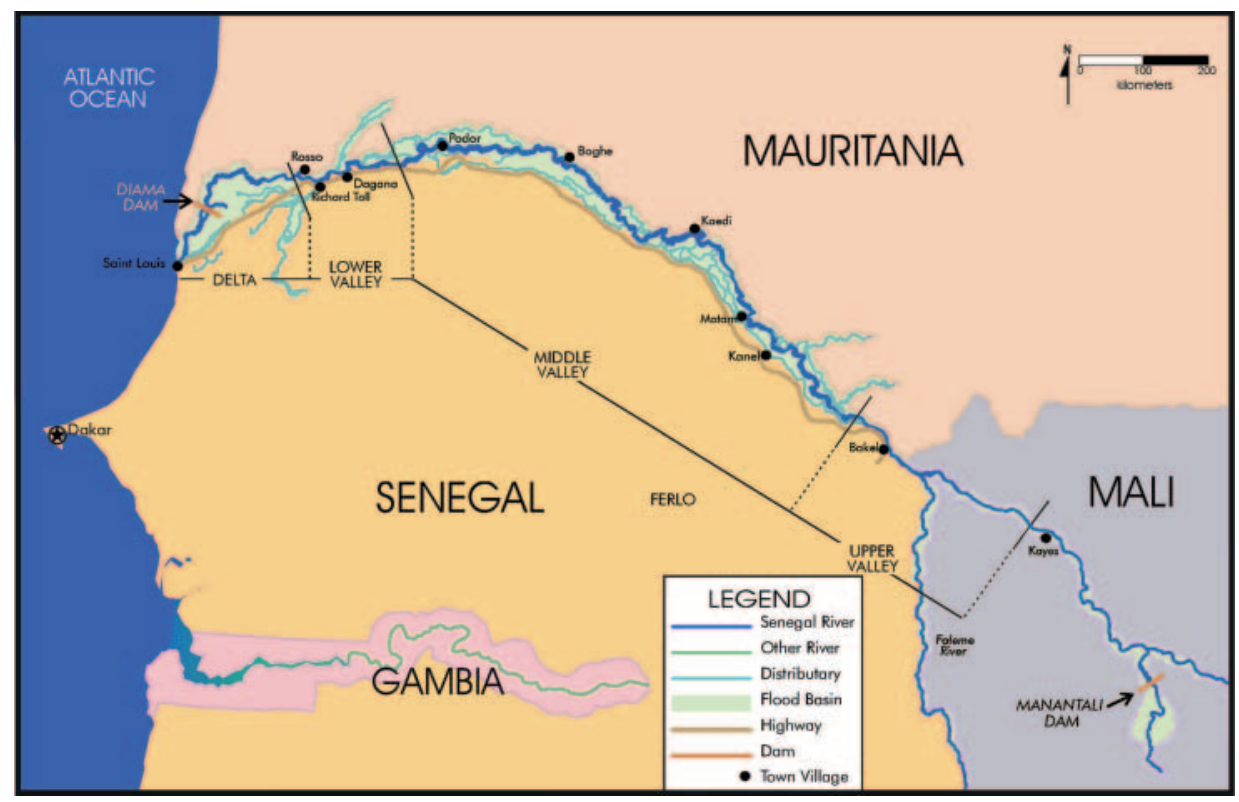

Fig. 1. Geographical regions of the Senegal River Valley 
of development for this region is a debate over 2 scenarios of time flow series analysis on the Senegal River based on recent historical decadal trends of wet and dry periods of stream flow. In essence, it is a scientific reading of the basin's past inter-annual and seasonal variability in precipitation and runoff, coupled with a probabilistic modeling of future climate trends in the region, that will ultimately shape the course of socioeconomic development of the Senegal River Valley.

This paper links both the biophysical and human dimensions of climate change by focusing first on a current reading of the climate literature for the Sahel region. It then scales down to a sub-regional assessment of critical climate variables shaping the lives of inhabitants in the Senegal Basin. Hypotheses regarding natural versus human-induced climate change, including the role of large-scale climate phenomena such as El Niño in shaping Sahelian rainfall, are examined, followed by an historical overview of climate trends for both the Sahel and the Senegal Basin. The historical dimensions of human adaptation to the seasonal and inter-annual vicissitudes of climate provide a longitudinal view of the political, social, economic, and environmental forces that have shaped changing food security strategies in the Upper Senegal Valley over the past century.

The second half of this paper shifts focus by examining the current dilemma of water resource constraint and regional intergovernmental attempts to resolve the precarious issue of transboundary water distribution and equitable access to water resources among potentially competing stakeholder interest groups. Critical to this assessment is a discussion of high and low flow time series analyses of the Senegal's waters and the perceived costs and benefits among the vying stakeholder groups according to the time series adopted.

The paper concludes by highlighting the central role of climate variability and technological intervention in shaping the future course of development in the Senegal Basin. Ultimately, this case study seeks to illustrate how an anthropological perspective can be useful in disaggregating broader, abstract global-scale climate analyses by revealing how climate variability has shaped individual community lives in the past and will inevitably determine the course of their future.

\section{NATURAL AND HUMAN-INDUCED CLIMATE CHANGE IN THE WEST AFRICAN SAHEL}

The west African Sahel has witnessed a secular trend of dessication dating back to the 1950s. ${ }^{2}$ This prompted many scholars in the $1970 \mathrm{~s}$, particularly social scientists, to argue that human alteration of the physical landscape played a larger role than perhaps previously suspected in creating a feedback effect on local and regional-scale climate phenomena. This thesis, termed the land-surface/atmosphere feedback hypothesis, posited that human-induced climate change resulted from anthropogenic degradation of forest cover, grazing lands, and modern farming methods such as extensive land clearing for irrigation. This position was particularly popularized by climate scholars such as Charney (1975) soon after the calamitous effects of the Sahelian drought. This position, however, is now refuted to a large degree by tropical meteorologists who contend that anomalous large-scale patterns of atmospheric circulation and their interaction with the hydrosphere, producing sea-surface temperature (SST) variations, account for much of the climatic change presently observed in the Sahel. Recent climate research from the Sahel suggests that while a very modest increase in surface albedo and dust particle generation has taken place in the recent past, the effect of such vegetative change on the regional climate has been nominal (Nicholson et al. 1998, Hulme et al. 2001). Nicholson (1989, p. 79) asserts that more recent research on the land-surface/atmosphere feedback hypothesis in the Sahel reveals that 'modification of the land surface might have sufficient impact on atmospheric conditions to intensify and perpetuate an existing drought, but not enough to initiate one' (emphasis added).

Nicholson (1989) supports this position by closely examining temporal and spatial variability in African rainfall continent-wide during the past century. Her analysis reveals large-scale spatial coherence in wet and dry patterns between subtropical and equatorial latitudes, with climate trends showing a frequent inverse relationship, leading her to conclude: 'This clearly implies that large-scale circulation changes, and not regional-scale phenomena, impose the dominant control on rainfall variability' (p. 81). She adds, however, that partial support for the human-induced land-surface feedback hypothesis may be evident when comparing the long-term temporal and spatial persistence of climate anomalies among regions on the continent. A low-frequency variance or decadal persistence of anomalous wet and dry years is exhibited more so in the Sahel than in other regions of Africa.

\footnotetext{
${ }^{2}$ Interestingly, conventional wisdom among many Sahelian scholars ubiquitously cites 1970 or 1972 as the point of departure for the drying of the region. However, Nicholson \& Palao (1993, p. 372) illustrate that, while the decade of the 1950s was exceedingly wet for the century, a downward trend in the standardized departure from the long-term mean in annual rainfall nonetheless begins at about 1950 and continues through 1990, with negative departures from the mean beginning at about 1968 .
} 
This unique Sahelian trend may be partial evidence of a 'more local positive feedback mechanism acting to reinforce rainfall anomalies initiated by large scale forcing' (Nicholson 1989).

Nicholson et al. (1997, p. 2981) suggest that surface hydrology may well be the critical feedback mechanism or biophysical parameter in the modulation of inter-annual climate variability in the Sahel. They conclude that hydrologic feedbacks may be a critical element in the intensification and prolongation of drought in the Sahel. This hypothesis may well be borne out in the case of the Senegal River Valley, where large-scale transformation of the basin's riparian ecology is taking place at unprecedented rates. The surface hydrology of the region is being drastically altered as a result of widespread leveling and denuding of the landscape for state-sponsored village cooperative irrigation projects, in tandem with the construction of a major high dam upstream at Manantali, Mali. In addition, the headwater flow of the basin upstream in the Fouta Djalon highlands of Guinea is threatened as tropical highland forests are cut, resulting in rapid vegetative cover loss, increasing gully erosion and siltation of the adjacent catchment zones downstream (Gilruth \& Hutchinson 1990).

Research by Venema et al. (1997, p. 125) on time series analysis of the Senegal Basin's hydrology suggests that the recent Sahelian drought may become a long-term feature of the regional landscape. They postulate that declining precipitation may be related to intensification of warm south-easterly trade winds possibly resulting from global warming, and biomass depletion due to deforestation, restricting northerly migration of the Inter Tropical Convergence Zone (Citeau 1992, in Venema 1997, p. 130). Corroborating analyses of hydrologic and rainfall data from other Sahelian river basins such as the Niger suggest that a trend of marked climate change may be taking place since 1960 (Sircoulon 1990).

\subsection{The role of ENSO in shaping climate variability in the Sahel}

The role of the El Niño/Southern Oscillation (ENSO) in shaping patterns of rainfall variability in the Sahel has been the focus of much scrutiny by climate scientists in recent years (Semazzi et al. 1988, Wolter 1989, Nicholson \& Palao 1993, Rowell et al. 1995, Nicholson \& Kim 1997). Influential studies such as that of Ropelewski \& Halpert $(1987,1989)$ and Nicholson \& Palao (1993) show an absence or very weak ENSO signal in the region. Recent work by Nicholson \& Kim (1997, p. 132) does suggest 'some evidence that ENSO may increase rainfall early in the season but decrease it later in the season, thus having no net influence on seasonal totals.' The timing of the ENSO signal in the region may be important, however, in terms of actual impacts on rural agriculture, since spatial and temporal distribution of rainfall, particularly the onset and end of the wet season, is essential in determining the outcome of crop productivity. As will be seen in a later section below, the distribution and timing of precipitation and flooding in Senegal River Valley production systems is critical to the positive outcome of any production season and the overall food security status of farm households.

Extensive paleoclimatic research on Africa has documented broad cyclical shifts between wet and dry periods, with each cycle lasting several thousand years (see Nicholson \& Flohn 1980, Street-Perrott \& Harrison 1985, Cockroft et al. 1987, Nicholson 1989). These broader temporal scales, however, are too coarse to detect variability on a shorter time horizon of years or decades. This paper, therefore, will limit itself to a much more refined climate analysis, beginning with some broader trends dating back several centuries, but focusing on more seasonal and inter-annual variability during the past century.

\section{BIOPHYSICAL DIMENSIONS OF CLIMATE VARIABILITY IN THE SENEGAL BASIN}

\subsection{Precipitation and runoff}

The Senegal River Valley, extending nearly 2000 km from its source in the Fouta Djalon highlands of Guinea to the Atlantic Ocean, traverses both the SudanoGuinean and Sahelian climatic zones, and constitutes the third largest wetland ecosystem in Africa (Grosenick et al. 1990, p. 120). The entire watershed covers an estimated $289000 \mathrm{~km}^{2}$ and supports approximately 2000000 inhabitants. The most salient feature of climate in the basin is the wide gradient of temporal and spatial variability in rainfall and runoff. In the basin's upper catchment alone, mean annual precipitation ranges from $2200 \mathrm{~mm}$ in the Fouta Djalon highlands to $600 \mathrm{~mm}$ in the Bafing and Bakoye tributaries in Mali (Lazenby \& Sutcliffe 1994, p. 503). Further downstream in the middle and lower zones, annual rainfall drops as low as 200 to $250 \mathrm{~mm}$. Precipitation falls intensively during a short 3 to 4 mo period from June or July through September, followed by a hot dry season. Between 1944 and 1985, 79.2\% of the annual runoff in the upper valley region occurred during the late wet season months of August to October.

Rural communities in the Senegal Valley have traditionally engaged in a mix of farming, fishing, and herding activities, relying heavily on a customary form 
of recessional floodplain farming. However, they have not always met their subsistence needs through these customary livelihoods. Frequent shortages in rain and nominal flooding of the wetlands has caused food shortage and famine (see Section 4.1), forcing individuals to migrate temporarily out of the region. The most recent large-scale migration resulting from drought conditions was the Sahelian drought of 1968-1974. ${ }^{3}$ This event prompted farm households throughout much of the basin to rely heavily on off-farm income remittances sent by migrant workers now residing in urban centers in Africa, France, and the United States.

Climate studies of the Senegal Basin generally mimic broader trends for the Sahel as a whole. For example, Citeau et al. (1989, p. 181, 183) detect a strong correlation in Senegal River runoff with annual rainfall patterns over the Sahel based on Lamb's rainfall variability index for the period 1965-1987 (Fig. 2). Nonetheless, a caveat is in order concerning broad sweeping generalizations about homogeneous climate patterns across the entire Sahel. Nicholson \& Palao (1993, p. 384), conducting a disaggregated analysis of rainfall variability by sub-region in the Sahel, demonstrated that statistically significant differences do exist among smaller regional zones, particularly in the northwestern sectors during the early months of rainfall in June-July. Some of these sectors correspond to the middle and lower regions of the Senegal Basin. Thus, the longer-term averaging of climate data trends from wet to dry periods in the Sahel must be interpreted with caution as they often mask seasonal and inter-annual variability, a critical climate feature shaping water resource availability for the region.

It is known that sizeable inter-annual variations in precipitation for the basin, and throughout the Sahel, result from the particular atmospheric conditions of the Inter-Tropical Convergence Zone (ITCZ). The seasonal movement of the ITCZ north from March to October, and south from November to February, creates an incremental range in wet and dry conditions in the valley according to the seasonal position of the ITCZ. The magnitude of drought conditions in the basin during the 1980s was characterized by a shift of the isohyet marking the northern limit of cultivation southwards by approximately $120 \mathrm{~km}$ to the Senegal-Mauritania border (OMVS/Dames and Moore International 1989, p. 3-39). According to Michel (1985, p. 114, 116), isohyets in 1972 had drifted southward by more than $200 \mathrm{~km}$ in relation to a previous $30 \mathrm{yr}$ period. A comparative analysis of decadal rainfall anomalies by

\footnotetext{
${ }^{3}$ Very severe drought revisited the region in 1984 . However, this was less prolonged than the Sahelian drought of the 1970s and did not culminate in extensive migration out of the region.
}

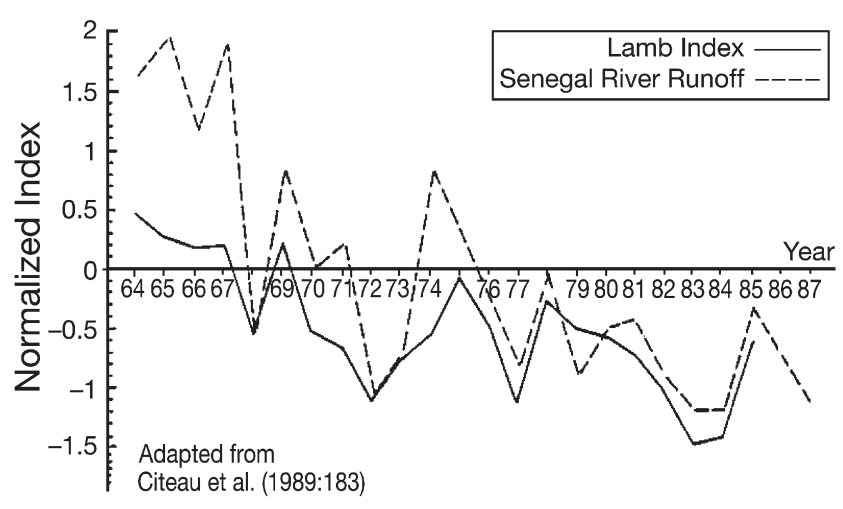

Fig. 2. Lamb Sahelian rainfall index and standardized anomalies of Senegal River runoff

Nicholson (1993, p. 1463) for 8 geographical zones of Sub-Saharan Africa illustrates that the 3 northernmost zones (Sahelo-Sahara, Sahel, Soudan) in which the Senegal Basin lies were abnormally dry in the 1970s and even worse in the 1980s. Thus, the severity of drought for the Senegal Basin, and for the Sahel as a whole, leads Nicholson (1993) to conclude, 'Overall the decade of the 1980s was the driest of the twentieth century for the continent as a whole and for West Africa in particular' (p. 1465).

A plethora of studies persuasively illustrate the severity of drought in the Senegal Basin over the past 2 decades (Gannett Fleming et al. 1978, GERSAR-CACG et al. 1989, Grosenick et al. 1990, Van Lavieren \& Van Wetten 1990). A recent review of rainfall data in the basin corroborates the broader secular drying throughout the Sahel in recent decades, indicating a reduction in average annual rainfall by more than $30 \%$ between 1930 and 1969, and 1970 and 1985 (Bass et al. 1995, p. 492). A comparison of annual rainfall totals at 4 regional locations in the Senegal Basin between relatively wet (1951-1971) and dry (1972-1998) phases shows a dry phase decline of about 30 to $40 \%$ with the exception of the most eastern station at Bakel, where decadal differences are less pronounced (Table 1). Rainfall averages in the wet phase are above the mean for the century, while dry phase figures are below it. An inter-annual trend in variability for all 4 sites (Fig. 3) and when averaged (Fig. 4) illustrates the spatial and temporal range of rainfall distribution.

Average annual flow of the Senegal River over a 30 yr period (1960-1990) closely parallels drying trends in rainfall, suggesting a possible long-term departure from average annual norms (Bass et al. 1995, p. 488). A comparison of decadal trends from 1951 to 1997 (Table 2) reveals that average annual flow in the 1990s (13 387 million $\mathrm{m}^{3}$ ) approaches the low flow years of the century in the 1970s (14616 million $\mathrm{m}^{3}$ ) and the 1980s (10194 million $\mathrm{m}^{3}$ ). This drying 
Table 1. Comparison of mean annual rainfall in the Senegal River Basin (rainfall in mm). Adapted from Hollis (1990, p. 7)

\begin{tabular}{|c|c|c|c|c|c|c|}
\hline Station & $\begin{array}{c}\text { Average } \\
1900-1998\end{array}$ & $\begin{array}{l}\text { Average }^{\mathrm{a}} \\
1951-1971\end{array}$ & $\begin{array}{l}\text { Average }^{\mathrm{b}} \\
1972-1998\end{array}$ & $\begin{array}{l}\text { Percent }{ }^{\mathrm{C}} \\
\text { reduction }\end{array}$ & $\begin{array}{l}\text { Minimum } \\
1972-1998\end{array}$ & $\begin{array}{c}\text { Maximum } \\
1972-1998\end{array}$ \\
\hline Saint Louis & 325 & 329 & 216 & 34 & 59 & 389 \\
\hline Podor & 265 & 315 & 193 & 39 & 66 & 340 \\
\hline Matam & 438 & 505 & 310 & 39 & 152 & 470 \\
\hline Bakel & 502 & 526 & 485 & 8 & 250 & 741 \\
\hline
\end{tabular}

trend is consistent with the decadal comparisons of regional rainfall patterns since the 1950s illustrated above. A linear regression in annual flow for the century shows an approximate halving from 30000 to 15000 million $\mathrm{m}^{3}$ at present (Fig. 5).

Stream flows recorded at Bakel for the period 1971-1990 are about half the flows for 1951-1970 (Lazenby \& Sutcliffe 1994, p. 503). Three periods of low stream flow for the basin correspond to those of low rainfall: 1911-1915, 1940-1944, and 1972-1992. This most recent phase of prolonged dryness (1972-1997) represents a deficit of $44 \%$ in annual average flow (12373 million $\mathrm{m}^{3}$ ) when compared to the average (22 106 million $\mathrm{m}^{3}$ ) for the period 1904-1997. Eighteen of the 20 driest years for the century were recorded during the 1972-1992 period, with average flow for 1984 (6695 million $\mathrm{m}^{3}$ ) being the lowest for the century (Albergel et al. 1993, p. 148).

\section{ADAPTATION TO EXTREME CLIMATE EVENTS IN THE SENEGAL RIVER VALLEY}

In essence, extreme climate variability has shaped the core features of economy, society, and subsistence livelihoods in the Senegal Valley. Exposure to the extremes of drought and flooding over the millenia has prompted a repertoire of human responses that has changed with the evolution of the economy and

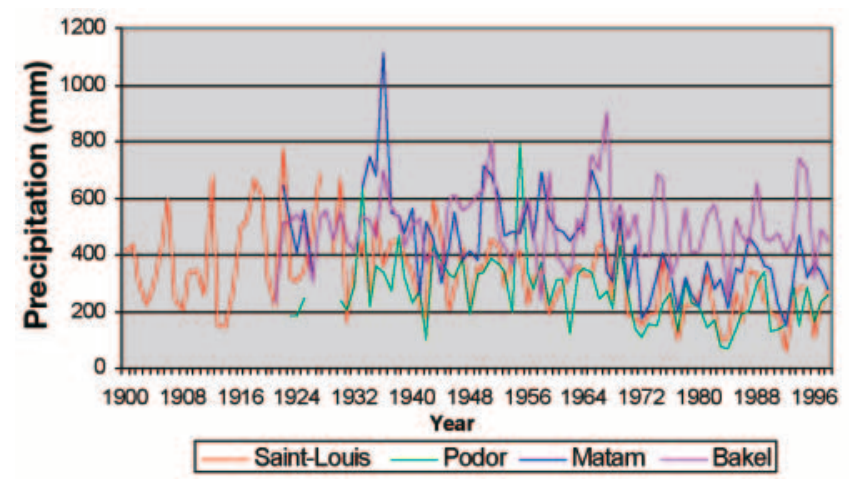

Fig. 3. Interannual variability in rainfall in the Senegal Basin, 1900-1998 $\left(\mathrm{mm} \mathrm{yr}^{-1}\right)$ increasing integration of local and global spheres of market exchange. By tracing human adaptive response to extreme climate events back in time, one can discern those critical variables that may or may not shape human response to climate change in the future. 'Forecasting by analogy' (Glantz 1988, 1992) has been employed as a historical methodological approach to understanding how a given society may react to future climate change by carefully examining past and present strategies of adaptation. This section provides a cursory overview of societal response to extreme climate vagaries in an attempt to shed light on potential future human response to anticipated climate change.

\subsection{Historical dimensions and human response to climate extremes in the upper Senegal River Valley}

The Senegal River Valley served as a vital entrepot and center of regional trade under the French colonial administration during the 19th century. French colonial records document the frequency of drought, often accompanied by famine, dating back to this period. Two social scientists (Chastanet 1992, Clark 1995) researching human response to environmental decline in the Upper Senegal Valley during the past century used archival records that make reference to famine epidemics as a proxy for drought conditions. Although not the sole contributing factor to famine in the region,

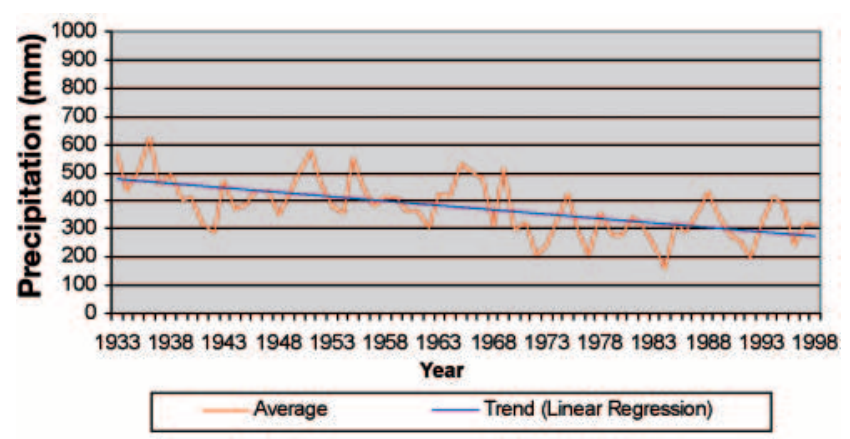

Fig. 4. Interannual variability in rainfall in the Senegal Basin, 1933-1998 $\left(\mathrm{mm} \mathrm{yr}^{-1}\right)$ 
Table 2. Decadal comparison of mean annual rainfall from 1951 to 1998 in the Senegal River Basin (rainfall in mm). Also shown are the percent change comparisons with the 1951-1960 average

\begin{tabular}{|c|c|c|c|c|c|c|}
\hline Station & $\begin{array}{c}\text { Average } \\
1951-1960\end{array}$ & $\begin{array}{c}\text { Average } \\
1961-1970\end{array}$ & $\begin{array}{c}\text { Average } \\
1971-1980\end{array}$ & $\begin{array}{c}\text { Average } \\
1981-1990\end{array}$ & $\begin{array}{c}\text { Average } \\
1991-1998\end{array}$ & $\begin{array}{c}\text { Average } \\
\text { Total }\end{array}$ \\
\hline Saint Louis & 330 & 342 & 211 & 226 & 206 & 265 \\
\hline$\%$ & - & +4 & -36 & -32 & -38 & - \\
\hline Podor & 360 & 287 & 193 & 175 & 208 & 246 \\
\hline$\%$ & - & -20 & -46 & -51 & -42 & - \\
\hline Matam & 546 & 471 & 289 & 345 & 307 & 395 \\
\hline$\%$ & - & -14 & -47 & -37 & -44 & - \\
\hline Bakel & 495 & 555 & 477 & 484 & 505 & 503 \\
\hline$\%$ & - & +12 & -4 & -2 & +2 & - \\
\hline Average & 433 & 414 & 292 & 307 & 306 & 352 \\
\hline
\end{tabular}

poor rainfall has nonetheless been a key variable shaping food insecurity in the region during the past century.

Chastenet (1992) and Clark (1995) documented how seasonal and inter-annual climate variability during the late 19 th and early 20 th centuries, intersecting with political and economic forces, was a critical variable in shaping food insecurity among area residents in the Upper Senegal Valley. The extremes of both drought and flooding could prove devastating for the outcome of a given agricultural season. Chastanet (1992, p. 136, 137) cites the most significant period of famine and scarcity in the upper valley regional town of Bakel as occurring from 1897 to 1915 with few years of adequate rainfall during this period. Other important years of what are termed 'great famines' include 1867-1869, 1905-1907, 1913-1915, 1926-1928, and 1944-1946. ${ }^{4}$ Thus inhabitants of this region, and most likely many others downstream in the middle and lower valley zones where rainfall isohyets decline, have been historically exposed on a periodic basis to extreme conditions of low rainfall and severe food deprivation. The most recent period in which famine was a widespread phenomenon in the basin was the Sahelian drought of 1968-1974 in which more than 100000 lives were claimed in 1973 alone (Nicholson 1989, p. 79).

\subsection{Changing human response strategies to famine}

Chastanet (1992, p. 137) discerns 3 distinct periods in which survival strategies and response to famine have changed in the Upper Senegal Valley: (1) the second half of the 19th century, (2) the first half of the 20th

\footnotetext{
${ }^{4}$ Chastanet (1992, p. 136) has developed a typology of famine conditions for the upper valley region of Bakel that includes: years of 'scarcity' (or disette in French) lasting up to 2 mo, 'famines' that occur from 3 to $8 \mathrm{mo}$, and 'great famines' that exceed 8 mo.
}

century, and (3) the 1960s to the present. During the past century, the gradual monetization of the local economy has witnessed an erosion of reliance on local production capacities, particularly under periods of climate stress, and a growing dependence on extra-local wage earnings to meet household consumptive needs.

With initial monetization of the local economy during the late 19th century, full reliance on local subsistence production began to change (Chastanet 1992, p. 142). Three common adaptive responses to famine during this period were grain expeditions by men, food gathering by women, and famine migrations primarily by males. Distinct gendered response was part and parcel of a famine crisis. Women would forage for wild edible plant species, while men would barter household goods (cloth, jewelry, etc.) for grain, often travelling considerable distances to do so. Men would also leave the region in search of employment in the groundnut basin or to neighboring urban centers. Chastanet notes that this pattern of famine migrations and grain expeditions actually persisted until the 1940s to 1950 s.

The most extreme response under periods of severe duress was for some families to resort to the selling off of slaves or the pawning of children in order to obtain necessary food stocks for survival. In general, during

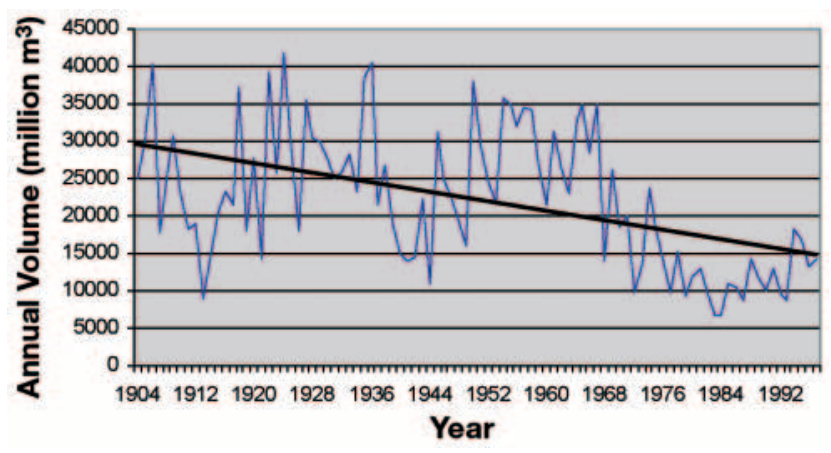

Fig. 5. Annual flow volume on the Senegal River al Bakel, 1904-1997 (million $\mathrm{m}^{3} \mathrm{yr}^{-1}$ ) 
past periods of subsistence crisis, an erosion of extended family ties and social cohesion would occur, such as the weakening of traditional patron-client relations between noble and servile social classes.

The early 20th century marked a phase of rapid monetization of the economy, resulting in the increased marketing of local subsistence crops. This had the effect of drawing down buffer stocks against years of bad harvest, forcing farm households to rely increasingly on migratory remittances (Chastanet 1992, p. 144). Wage labor migration served as a doubleedged sword, eroding the local productive capacity of the region, yet also reducing rates of mortality during famine periods. Chastanet (1992) argues that, 'While migrations have been factors in food crises, with the gradual monetization of the economy they have also for some time now helped attenuate the gravity of those crises.'

Prior to market integration of the local economy, famines were characterized by high mortality rates as a result of disease epidemics, thus acting as a significant brake on demographic growth.

From 1954 to 1982, with near total integration of the local and regional economy into larger spheres of capitalized markets, and increased dependence on extra-local wages and migrant remittances, population growth began to explode, more than doubling to $3 \%$ (Chastanet 1992, p. 145). This reflects patterns of rapid migration to France in the 1960s. By the mid-1970s, migration of adult males from the Bakel region had risen from 30 to $50 \%$ (Weigel 1982, p. 24).
Iliffe (1990) has described this increased absorption of male labor into monetized economic spheres outside the region and an increasing reliance on extra-local wages to buffer against periods of climatic vagary as a 'capitalist system of famine control.'

\section{AGRO-ECOLOGICAL RESPONSE TO CLIMATE VARIABILITY IN THE SENEGAL BASIN}

The ecology of the Middle Senegal River Valley features a mix of habitats that collectively constitute a wetland mosaic. Discrete ecological zones, each with their own physical features and subsistence resource base, are dispersed laterally from the river across the valley floor (Fig. 6). Farming, herding, and fishing livelihoods are practiced in relation to the ecological features of each zone. Each microenvironment has a distinct geomorphology, soil structure, ecology, and plant species composition contributing to the biological diversity of the region.

This riparian wetland provides a sequential spacing of crop harvests over the course of a year, thereby smoothing cyclical phases of crop surplus and shortage between wet and dry seasons and attenuating bouts of food scarcity. Upland rainfed fields (jeeri) and floodplain bottomlands (waalo) act as a relay cropping system (Adams 1985, p. 295), providing vegetables and cereal grains, as well as fodder for small livestock between the rainfed harvest in November and the recession floodplain harvest in March-April.

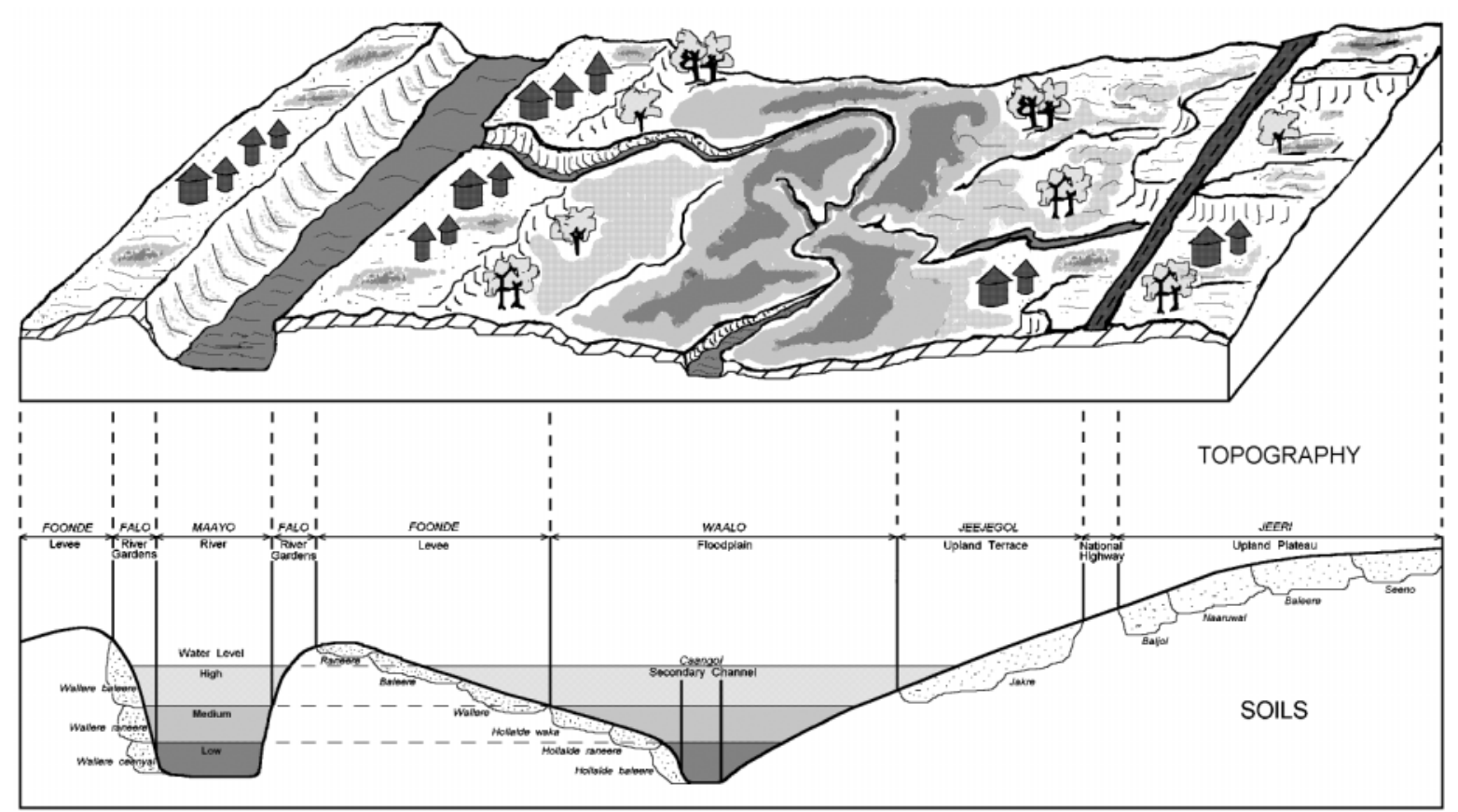

Fig. 6. Middle Senegal River Valley, featuring discrete ecological zones dispersed laterally from the river across the valley floor 
The full functioning of this system depends, however, on adequate rainfall and hydrological runoff on a seasonal and inter-annual basis. During a year of evenly distributed rainfall between the months of July and September, farmers plant a variety of sorghum (fela) that is well adapted to the dry conditions of the high river levy and adjacent high plains (foonde). This period also corresponds to the planting of finger millet (suuna) by farmers and herders dwelling in or near the sandy upland zone (jeeri). A harvest of this rainfed crop in November overlaps with the planting of the recession bottomlands (waalo) and river bank gardens (falo), which are inundated under years of normal flooding from August to mid-October. When the river floods, the bottomlands also become the site of intensive fishing activity as area fishers follow the migration of fish that move into the plains to spawn and feed in the fertile bottomland waters. In years of poor local rainfall and failure of the rainfed harvest in November, valley farmers must rely heavily on an adequate flood and bottomland crop harvest in March-April in order to avoid a total depletion of food stocks early in the dry season. An extended harvest period from December to March of garden vegetables, melons, legumes, and maize on the river bank's edge is also extremely critical to the nutritional welfare of the population early in the dry months (Magistro 1994).

Bottomland flooding is also critical to the welfare of a third socioeconomic group, FulBe pastoralists, who migrate seasonally northward from a neighboring upland zone to graze their herds on sorghum stover in bottomland fields at the end of the crop harvest in April. This mass movement of livestock into the floodplain (termed nyaangal) permits a rich nutrient exchange of cellulose and manure on the bottomlands. This enables the reconstitution of area herds during the harsh dry season and simultaneously enables local farmers and fishers to benefit from the manuring of floodplain soils.

\section{WATER RESOURCE CONSTRAINT AND AGRO-HYDROLOGICAL DEVELOPMENT OF THE SENEGAL BASIN}

With the onset of persistent Sahelian drought by the early 1970s, government authorities in the affected basin area from Senegal, Mali, and Mauritania embarked on an ambitious river basin development initiative to curb the most severe effects of drought and food insecurity in the region. In 1972, a tri-national river basin commission, the OMVS (Senegal River Valley Development Authority), was created with bi- and multilateral donor assistance. Its mission was to manage a system of dams for purposes of hydroelectric power generation, the development of capital-intensive irrigation, and the eventual creation of a navigable waterway and inland port at Kayes, Mali. The dams currently operating at Diama and Manantali since the mid-1980s now stabilize the seasonality of stream flow, enabling a double crop season of rice harvests on irrigation schemes during the year.

Since the early 1970s, irrigation systems have been expanding to supplement rainfed and flood recession crops, and to act as a safety net, buffering against crop shortages in years of poor rainfall and flooding. The projected expansion of irrigation schemes since operation of the dams in 1987 to 375000 ha at an annual rate of increase of 5000 ha has fallen far short of initial expectations for multiple reasons. ${ }^{5}$ These include high production costs, low yields per unit labor and capital, poor infrastructural development and scheme maintenance, and a lack of internal social cohesion and organization. There is extensive documentation of poor irrigation performance for technical, economic, and sociological reasons (see Niasse 1990, Horowitz et al. 1991, Magistro 1994). Schemes are presently operating at below $50 \%$ of projected capacity with cropping intensities at only $60 \%$ of capacity in the wet season and $20 \%$ in the dry season (OMVS/ORSTOM 1997, p. 5-6). As of 1988, only an estimated 39270 ha of irrigation land has been developed in Senegal and 16856 ha in Mauritania (Woodhouse \& Ndiaye 1990, p. 4). Irrigation construction costs alone are estimated at \$25000-40000 ha ${ }^{-1}$.

An extended delay in the installation of turbines for hydroelectric power generation has led the OMVS to operationalize a transitional flood release strategy enabling farmers downstream from the Manantali Dam to continue customary cultivation of their recession bottomland fields. This would continue until installation of the dam's turbines for hydroelectric generation (now projected for approximately 2000/2001), at which time a constant year-round flow of water through the dam for power generation purposes would suppress any future flooding from the impounded tributary, the Bafing River. Flood releases would occur in years of extreme rainfall and flooding when waters exceed the $208 \mathrm{~m}$ limit in the reservoir or as long as discharges do not reduce stated output goals for hydropower generation. During the transitional flood release period, waters have been released to test the structural integrity of the dam. The timing of these releases has destroyed the seeding of floodplain fields

${ }^{5}$ OMVS planning documents forecast an eventual attainment of a maximum of 375000 ha into the early part of the 21st century. However, current levels are far below and were estimated at approximately 100000 ha in 1996 (World Bank 1997, p. 1). 
on several occasions since operation of the dam (see Horowitz et al. 1991).

The premises under which suppression of the natural flood regime would take place, and the original objectives in building the dams, have been contested in recent years (see Horowitz et al. 1991). At the heart of the debate is a focus on inter-annual and seasonal variability in stream flow and associated high and low flow time series analyses that determine different benefit-cost ratios and capital rates of return that, as of yet, remain unresolved. Attention turns now to this debate and the salient role that climate variability will play in shaping future water user demand in the Senegal Basin.

\subsection{Climate variability and the Manantali Energy Project}

The Manantali Dam, costing approximately \$637 million (World Resources Institute et al. 1998, p. 114), was completed and began operation in 1988. The accompanying hydroelectric component (turbines, transmission lines), scheduled for completion by October 2001, has been projected to cost an additional \$445 million, bringing the total cost of the dam in excess of $\$ 1$ billion. Five $40 \mathrm{MW}$ turbines will have the capacity to generate $200 \mathrm{MW}$ of hydroelectricity with an annual average energy output of $804 \mathrm{GWh} .{ }^{6}$ Power transmission lines will follow the river valley to the urban capital cities (Dakar, Bamako, Nouakchott) of the 3 OMVS member states.

Substantial donor contributions from bi- and multilateral development institutions such as the World Bank and the African Development Bank base their lending portfolio on standard benefit-cost analyses that are grounded in climatological assumptions concerning the inter-annual variability of stream flow on the Senegal River. Two hydrological scenarios - a high flow period from 1950 to 1994 and a low flow period from 1970 to 1994 - are used as reference points in calibrating differential donor returns on investment. ${ }^{7}$ The past 30 yr climate record (since about 1968) for the region shows a significant statistical downward trend in mean annual stream flow on the Senegal River. ${ }^{8}$ This raises the critical question of which hydrological time frame, more recent decadal variability or a longer-term historical record, should be adopted

\footnotetext{
${ }^{6}$ This figure is based upon hydrological flow data from 1950-1994 and an assumption that rainfall and runoff levels will return to an earlier pre-1970 wet period.

${ }^{7}$ Interestingly, these hydrological scenarios have only recently been analyzed in terms of future decision-making for management of the dam. Scenarios of future climate variability based on past historical records were not explicitly a part of planning and design in early stages of pre-dam feasibility studies and at the time of construction of the dams.
}

in building a realistic cost-return ratio. Hydrological analyses based on observational trends in historical flow data must be complemented with a sounder assessment of probabilistic climate forecasting trends for the coming century. What do current climate change models suggest concerning future patterns of rainfall and stream runoff for the basin? Will a continued rise in greenhouse gas emissions lead to a continued warming trend in mean temperatures for the Sahel? Will such a trend be associated with a continued decline in mean annual rainfall for the region?

\subsection{Wet and dry flow time series analyses}

Two time flow analyses have been developed to compare the costs and benefits of meeting multi-user water needs on the Senegal River. At question is whether sufficient river discharge will exist annually to meet 3 major objectives: (1) the generation of 804 GWh of electricity (or $574 \mathrm{GWh}$, depending on the time series adopted), (2) the year-round availability of water to irrigate 375000 ha of land, and (3) a seasonal release of flood waters from the Manantali Dam to allow for cultivation of 50000 ha of flood recession bottomland. ${ }^{9}$ In determining the tradeoffs among these multiple demands, wet and dry flow scenarios become the critical factor that will shape future policy on water resource management for the end users.

Based upon average annual hydrological flow at Bakel, the interstate river basin commission, OMVS, with assistance from French bi-lateral aid (OMVS/ ORSTOM, p. 1997), has undertaken a comparison of 3 water resource scenarios using 2 time flow series for 1950-1997 and 1970-1997 (Table 3). ${ }^{10}$ Under Scenario

\footnotetext{
${ }^{8}$ As noted earlier in the work of Nicholson et al. (1997), downward trends actually begin in 1950, despite this decade being an anomalous wet period for the century. However, hydrologists use the post-1950 and post-1970 time frames as a point of statistical comparison between representative wet and dry periods for the century.

${ }^{9}$ This minimum area of cultivation, frequently referred to as the Gibb A hydrogram, is based upon hydraulic analyses by Sir Alexander Gibb and Partners et al. (1987), in which low, average, and high flood volume scenarios were developed using observational flow data dating back to the beginning of the 1900s, when the first hydraulic stations were set up along the river. Although the precise relationship between flood area inundated and area cultivated is still not determined (Hollis 1990), it is estimated to be about $50 \%$. Thus a Gibb A hydrogram allows for a 100000 ha flood of which an estimated 50000 ha are cultivated.

${ }^{10}$ Figures from Table 3 are based on a reservoir simulation model conducted by J. P. Lamagat, a French hydrological engineer with ORSTOM (Lamagat 1996), and an OMVS/ ORSTOM 1997 key document analyzing the 3 scenarios presented.
} 
Table 3. Economic costs and benefits of operating strategies for the Manantali Reservoir. I: irrigation; F: flood recession; E: energy production. (Adapted from OMVS/ORSTOM 1997, p. 14,17)

\begin{tabular}{|c|c|c|c|c|c|c|}
\hline & \multicolumn{3}{|c|}{ Wet flow (1950-1997) } & \multicolumn{3}{|c|}{ Dry flow (1970-1997) } \\
\hline & $\begin{array}{l}\text { Scenario A } \\
\text { (IF) }\end{array}$ & $\begin{array}{l}\text { Scenario B } \\
\text { (IE) }\end{array}$ & $\begin{array}{l}\text { Scenario C } \\
\text { (IFE) }\end{array}$ & $\begin{array}{l}\text { Scenario A } \\
\text { (IF) }\end{array}$ & $\begin{array}{l}\text { Scenario B } \\
\text { (IE) }\end{array}$ & $\begin{array}{l}\text { Scenario C } \\
\quad \text { (IFE) }\end{array}$ \\
\hline Annual energy output GWh & 754 & 874 & 808 & 637 & 768 & 653 \\
\hline Floodplain area cultivated $\times 10^{3}$ ha & 80 & 61 & 71 & 42 & 12 & 32 \\
\hline $\begin{array}{l}\text { Energy loss GWh } \\
\times 10^{3} \$\end{array}$ & 120 & - & $\begin{array}{r}66 \\
-9240\end{array}$ & 131 & - & $\begin{array}{c}115 \\
-16100\end{array}$ \\
\hline $\begin{array}{l}\text { Agricultural gain } \times 10^{3} \text { ha } \\
\times 10^{3} \$\end{array}$ & $\begin{array}{l}- \\
-\end{array}$ & - & $\begin{aligned} & 10 \\
+ & 4580\end{aligned}$ & $\begin{array}{l}- \\
-\end{array}$ & $\begin{array}{l}- \\
-\end{array}$ & $\begin{array}{c}20 \\
+9161\end{array}$ \\
\hline $\begin{array}{l}\text { Net balance GWh } \\
\times 10^{3} \$\end{array}$ & - & - & $\begin{array}{r}33.3 \\
-4659\end{array}$ & - & - & $\begin{array}{r}49.6 \\
-6939\end{array}$ \\
\hline
\end{tabular}

A, irrigation and flood recession cultivation is given priority over hydropower production. Scenario B privileges irrigation and hydropower over floodplain farming. ${ }^{11}$ Scenario $\mathrm{C}$ is a balanced multi-use strategy, calling for water releases from the reservoir to generate the targeted goals of hydroelectricity, irrigation, and floodplain cultivation described above.

Figures on flood cultivation in Table 3 reveal that under a dry flow scenario, the minimum 50000 ha flood called for in the Gibb A hydrogram would be reduced to 32000 ha. On average, power production (Scenario B) would reduce annual flooding by 20000 ha from 32000 to 12000 ha. Under the wet flow scenario, this loss would be at only 10000 ha (from 71000 to 61 000). Maintenance of an artificial flood under Scenario $C$ would reduce hydropower annually by 115 GWh $(15 \%)$ under the dry period, and by only 66 GWh (7.6\%) under the wet period.

\footnotetext{
${ }^{11}$ Only under Scenario B would a maximum of 375000 ha be attained.

${ }^{12}$ Data are drawn from multiple sources (Horowitz et al. 1991, p. 25,33, Magistro 1994, World Bank 1997, p. 100-102) to assign market values to energy production, floodplain farming, herding, and fishing, as well as the cost of potable water supply lost under a no-flood scenario. Other ecological values such as flood-dependent forest regeneration of a highly valued tree species, Acacia nilotica, and losses in biodiversity habitat such as adverse impacts on waterfowl and changes in migratory bird species composition at Njoudj National Park in the lower valley delta are not factored into the benefit-cost analysis. Accounting for these, and potentially other basic ecological functions and values, would significantly increase the economic valuation of floodplain lands.

The market values used in Table 3 include: flood recession waalo cultivation of sorghum valued at CFA Franc $64000 \mathrm{ha}^{-1}$ (CFAF $107 \mathrm{~kg}^{-1}$ in 1995), river bank falo garden cultivation valued at CFAF $772530 \mathrm{ha}^{-1}$ (cowpeas CFAF $11700 \mathrm{ha}^{-1}$, maize CFAF $222530 \mathrm{ha}^{-1}$, sweet potatoes CFAF $363300 \mathrm{ha}^{-1}$, tomatoes CFAF $175000 \mathrm{ha}^{-1}$ ), livestock live weight valued at CFAF $50000 \mathrm{ha}^{-1}$ (CFAF $600 \mathrm{~kg}^{-1}$ ); floodplain fisheries at CFAF $70000 \mathrm{ha}^{-1}$, and the loss of potable water supply estimated at CFAF $6400 \mathrm{ha}^{-1}$ (see sources above for calculation of these values). All production systems are based upon the
}

\subsection{Hydrological variability and economic costs and benefits of water use scenarios}

Given the estimated differences between wet and dry flow time series impacts on hydropower and flood cultivation production, it is also possible to perform a modified benefit-cost analysis that weighs the economic advantages and disadvantages associated with each strategy. An evaluation of ecological benefits in terms of primary production generated from the floodplain is assigned to the multi-use scenario (Scenario C) and compared to the economic return on hydropower maximization (Scenario B) in Table 3. ${ }^{12}$

The annual reduction of 20000 ha of cultivated recession land due to hydropower generation under the dry flow series would mean an annual average loss of

10000 to 20000 ha gains in Scenario C with the exception of falo garden production (based upon a 500 ha gain). Electricity is valued at $70 \mathrm{CFAF} \mathrm{kWh}^{-1}$. The conversion rate used is $\$ 1=$ CFAF 500 and accounts for the doubling of market crop values after devaluation of the CFAF in January 1994.

This analysis contests the methodological assumptions used by the World Bank in which the value of fisheries, forest regeneration, and ground water supply are not built into their benefitcost analysis. In addition, their analysis gravely omits the high market value of river bank gardens, a flood recession system providing a significant source of household income for women that has been grossly overlooked in the research literature from the region. For example, the Bank argues that the floodgroundwater recharge linkage has not been conclusively established (World Bank 1997, p. 100, 105). This observation contrasts sharply, however, with the findings of several hydraulic studies that examine the linkage between river flooding and aquifer recharge in the basin. Results of studies on the flood-aquifer recharge by Illy (1973), GERSAR/CACG et al. (1988), and OMVS/ISTI (1990) provide strong evidence that 'the surface aquifer is in direct communication with the river and is recharged during floods via the permeable deposits rather than from rainfall' (Hollis 1996, p. 171). Based upon the consistency of these findings, Hollis (1996) concludes that 'the river flood provides most of the recharge of the aquifers under the valley' (p. 172). 
approximately $\$ 9$ million of primary production. This loss would be slightly more than one-half (\$4 580500 ) under the wet flow scenario. Support of an artificial flood would reduce hydropower by $115 \mathrm{GWh}$ or an annual average loss of approximately $\$ 16$ million under the dry flow. This loss would be 66 GWh or just over $\$ 9$ million under the wet flow series.

If a flood regime under Scenario $\mathrm{C}$ were maintained, the net loss to hydropower would actually be lower when the gains in primary production of $\$ 4.6$ to $\$ 9.1$ million are taken into account. The true net loss in hydropower would range from 33.3 to $49.6 \mathrm{GWh}$ (\$4659000 to $\$ 6939000$ ), depending on wet versus dry flow outcomes. As noted, the gain in primary production does not take into account critical ecological functions and values that are not easily quantifiable for conventional economic purposes. The World Bank itself acknowledges these values and concludes in its own benefit-cost analysis in a critical strategic planning document on the Manantali Energy Project that 'including the non-quantified social and environmental benefits would swing the balance in favor of the flood.' Furthermore it adds that 'eliminating the flood entirely to maximize electricity output would be too costly for a multitude of economic, social, political and environmental reasons' (World Bank 1997, p. 101-102).

\subsection{Adaptation outcomes}

The implications of this benefit-cost analysis in terms of human response and adaptation to future scenarios of hydrological variability and climate change are significant. Agrarian communities in the Senegal River Valley already experience very high levels of out migration of productive male farm labor from the region, both seasonally and long term. According to the logic of the OMVS member states, it is assumed that an energy maximization scenario (Scenario B) will act as a brake on historically high rates of out migration, drawing men back to the valley in order to become full-time rice farmers. However, present experience with irrigated rice farming in the region over the past 3 decades does not persuasively support the OMVS assumption of a return exodus of able-bodied young men back to the valley. To the contrary, preliminary research findings suggest that the capital-intensive outlays of irrigation farming and poor returns per unit labor and capital may actually propel the departure of male labor in search of wages for productive investment in rice farming rather than impede it (Magistro 1994).

The regularization of stream flow for energy and irrigation purposes could be advantageous in times of extreme inter-annual variation. Without flood control or stream regularization, years of extreme drought or high flooding could prove devastating, particularly in an unforeseen scenario of future climate change. Therefore, a Scenario B strategy would be advantageous in those years of extreme climate anomaly. Predicting the frequency of those extremes in the coming century, however, remains highly uncertain among climate forecasters and climate change modelers.

Institutionally, Scenario B should prompt increased agricultural production, both for household consumptive use and for local and extra-local markets, thus reducing government expenditures on imported rice and key staple grains. Evidence from the past decade, however, does not support this observation. Agricultural trends reveal a stagnation in rice production in the Senegal River Valley, largely as a result of the dismantling of state subsidies and a sudden precipitous rise in production factor costs with currency devaluation in January 1994 (Magistro 1995). Consequently, imported rice has come to provide four-fifths of the country's consumptive needs in recent years (TardifDouglin et al. 1998, p. 15).

Regularization of stream flow for hydropower maximization and year-round irrigation also has adverse consequences for seasonal fisheries and the migratory spawning of freshwater fish species that are dependent on annual flooding and discharge of waters into the low-lying floodplain. Food security and the adaptive management of area fisherfolk is threatened when fish are no longer able to feed and spawn in the fertile bottomland plains adjacent to the river. Scenario B, then, does not necessarily assure greater food security in terms of both cereals and fish production for the Senegal Basin in an average year of 'normal' climate conditions. It does place individuals at greater risk by narrowing the range of farm production strategies available and creating more dependence on capitalintensive farm technology.

A multi-use strategy (Scenario $C$ ) that balances the demands for hydroelectricity and year-round irrigation with a seasonal release of flood waters for downstream ecological maintenance and livelihood diversification enables a form of adaptive farmer response that (in an average year of climate) is more flexible and responsive to the needs of local communities. Seasonal flooding of the area plains and the banks of the river enables farmers to spread risk by employing a broader repertoire of farming strategies (bottomland recession, river bank horticulture, floodplain fishing), and reducing economic dependence on capital-intensive rice farming. Valley farmers, when weighing the opportunity cost of local farm strategies, find the returns from off-farm wage income to exceed the modest returns to all farming systems presently available, both modern (irrigation) and customary (recession). Thus, in years 
when ample flooding does occur, smallholders invariably resort to recession farming of the bottomland plains - a strategy of low labor and capital investment-in order to free up the most productive segment of the labor force for seasonal wage migration to larger centers of population.

In sum, a year of average climate in the Senegal Valley confers advantage to area farmers under a multiuse water resource management strategy (Scenario C), while years of extreme climate (severe drought, high flooding) confer advantage to an energy maximization strategy (Scenario B). ${ }^{13}$ In the end, neither scenario appears to successfully address concerns about the outward orientation of the labor force, which does appear to prove beneficial under conditions of extreme climate stress. Migratory remittances for cash purchases of food during years of severe drought or flooding has become the lifeline for survival of many families during such episodes. Under a future climate change scenario of increasing extreme climate events, one can assume, using historical analogy as a predictive model (Glantz 1988, 1992), that resident farmers will increasingly rely on outside remittance earnings to tide them over during such difficult periods. This outward-oriented capitalization of food security, or 'capitalist system of famine control' (Iliffe 1990) has paradoxically proven more secure as a famine mitigation strategy than earlier famine episodes during the century when outward migration was much lower.

\section{CONCLUSION}

Social scientists conducting research at sub-regional scales on the human dimensions of global environmental change recognize the inherent limitations of conventional climate impact assessments to adequately identify human level impacts of warming of the earth's atmosphere (Glantz 1992, Stern et al. 1992, Ribot et al. 1996, Smithers \& Smit 1997). As this paper suggests, finer scales of resolution and analysis of spatial and temporal processes of human-climate interaction at

\footnotetext{
${ }^{13}$ It is important to note that the benefits and costs associated with each management strategy discussed in this paper do not take into account a broader set of issues that are impossible to quantify as a net gain or loss, but which nonetheless seriously affect the lives of inhabitants in the valley. For example, a ruling elite of Arab-Berber Maures (bidans) has forcefully expropriated valuable farm lands from black subSaharan Africans for irrigation purposes on the Mauritanian side of the river during the past decade. The devastating loss of such productive lands fueled, in part, a major ethnic conflict on the border in 1989 (see Horowitz 1989, 1993, Magistro 1993, 1994). Such human dimensions of water resource use are easily overlooked in conventional benefitcost analyses in international development.
}

regional, sub-regional, and local levels are needed. It is not yet clear precisely how current scales of futureoriented global climate research might intersect with the immediate realities and preoccupations of impoverished communities living at the economic margins in much of the developing world.

This paper seeks to scale down current generalized analyses on climate by specifically addressing a subset of human-related issues on climate change-interannual and seasonal variability and its impacts on society in a riparian Sahelian context. An anthropological focus on historical, social, economic and political context at a regional level is integrated with biophysical parameters of climate in addressing a contentious debate about future water resource management in the Senegal River Valley. Policy decisions required to balance multi-water use objectives for energy production, expansion of irrigation agriculture, and flood simulation for downstream production and ecosystem conservation will be determined in part by improved scientific modeling and forecasting of inter-annual and seasonal discharge of the river's waters. Hydrological and climate forecasting models alone, however, are not sufficient to determine the future course of water user demand for the region. This paper has examined the tradeoffs in operating strategies of the Manantali Dam under wet and dry time flow scenarios, taking into account an array of socioeconomic and environmental concerns that may easily be overlooked when carrying out conventional benefit-cost analyses. A broader anthropological perspective on a wide range of both biophysical and human variables has been presented here with the hope that more informed policy decisions will be made with respect to the future management of the Senegal Basin. Such critical decisions, circumscribed by current global concerns about climate impact mitigation and adaptation, will shape the lives of inhabitants of the Senegal Basin in the new millenium.

Acknowledgements. The authors wish to express their gratitude to Dr William A. Cooper, Director of the Advanced Study Program, and Dr Kathleen Miller, Interim Director of the Environmental and Societal Impacts Group at the National Center for Atmospheric Research, and the Centre de Suivi Ecologique in Dakar, Senegal, for providing logistical support and an NCAR research grant for field studies in Senegal during the period October-November 1998. In addition, Dr Michael Horowitz, Co-Director of the Institute for Development Anthropology, supervised the doctoral research of John Magistro under a USAID-funded multi-year research initiative, the Senegal River Basin Monitoring Activity (SRBMA), on which part of this work is based. The Social Science Research Council provided partial financial support during the write-up phase of the doctoral research. Much gratitude also goes to Dr Thayer Scudder, Co-Director at IDA, and Dr Curt Grimm for helpful comments, Teressa Heywood for assistance with figures and graphics, and to the anonymous 
reviewers of this paper. The views are solely those of the authors and in no way reflect the official opinion or position of the funding or sponsoring institutions mentioned above.

\section{LITERATURE CITED}

Adams WM (1985) The downstream impacts of dam construction: a case study from Nigeria. Trans Br Inst Geogr New Ser 10:292-302

Albergel J, Bader J, Lamagat J, Séguis L (1993) Crues et sécheresses sur un grand fleuve tropical de l'ouest africain: application B la gestion de la crue de fleuve Sénégal. Secheresse 4(3):143-152

Bass B, Venema H, Schiller E (1995) Adaptation of food production to drought in the Senegal river basin. In: Downing TE (ed) Climate change and world food security. SpringerVerlag, Berlin, p 485-503

Charney JG (1975) The dynamics of deserts and droughts. Q J R Meteorol Soc 101:193-202

Chastanet M (1992) Survival strategies of a Sahelian society: the case of the Soninke in Senegal from the middle of the nineteenth century to the present. Food Foodways 5(2): $127-149$

Citeau J (1992) Les satellites météreologique, une approche nouvelle de la connaissance du climat du Sahel. Thèse du doctorat de l'université Paul Sabatier, Toulouse, Centre d'Etudes Spatiéle des Rayonnements

Citeau J, Finaud L, Cammas JP, Demarcq H (1989) Questions relative to ITCZ migrations over the tropical Atlantic Ocean, sea surface temperature and Senegal river runoff. Meteorol Atmos Phys 41:181-190

Clark A (1995) Environmental decline and ecological response in the upper Senegal valley, West Africa, from the late nineteenth century to World War I. J Afr Hist 36: 97-218

Cockroft MJ, Wilkinson MJ, Tyson PD (1987) The application of a present-day climatic model to the late quaternary in southern Africa. Clim Change 10:161-181

Dow K (1992) Exploring differences in our common future(s): the meaning of vulnerability to global environmental change. Geoforum 23(3):417-436

Gannett, Fleming, Cordrry, Carpenter (1978) Assessment of environmental effects of the proposed developments in the Senegal river basin. Partial report for fisheries. OMVS, Dakar

GERSAR-CACG, EUROCONSULT, Sir Alexander Gibb, SONED (1988) Plan directeur de développement intégré pour la rive gauche de la vallée du fleuve Sénégal: scheme directeur de Matam. Document provisoire. 3 Vols. PNUD/ BIRD, New York

GERSAR-CACG, EUROCONSULT, Sir Alexander Gibb, SONED (1989) Plan directeur de développement intégré pour la rive gauche de la vallée du fleuve Sénégal: rapport d'etape. PNUD/BIRD, New York

Gilruth P, Hutchinson C (1990) Assessing deforestation in the Guinea highlands of West Africa using remote sensing. Photogramm Eng Remote Sensing 56(10):1375-1382

Glantz MH (1988) Societal responses to regional climatic change: forecasting by analogy. Westview Press, Boulder, $\mathrm{CO}$

Glantz MH (1992) Global warming and environmental change in sub-saharan Africa. Global Environ Change 2(3):183-204

Grosenick G, Djegal A, King JW et al. (1990) Analyse pour la gestion des ressources naturelles du Sénégal: rapport final. (PDC-5517-I-13-7136-00). Louis Berger International/ Institute for Development Anthropology, Washington, DC Hollis GE (1990) Senegal river basin monitoring activity: hydrological issues. Part I. Senegal river basin monitoring activity I (SRBMA I)/IDA working paper no. 56. Institute for Development Anthropology, Binghamton, NY

Hollis GE (1996) Hydrological inputs to management policy for the Senegal river and its floodplain. In: Acreman MC, Hollis GE (eds) Water management and wetlands in subsaharan Africa. IUCN, Gland, p 155-184

Horowitz MM (1989) Victims of development. Dev Anthropol Net $7(2): 1-8$

Horowitz MM (1993) Development-induced food insecurity in the middle Senegal valley. GeoJournal 30(2):179-184

Horowitz MM, Salem-Murdock M, Grimm C et al. (1991) The Senegal river basin monitoring activity, phase I: synthesis report. Institute for Development Anthropology, Binghamton, NY

Hulme M, Doherty R, New M, Ngara T, Lister D (2001) African climate change: 1900-2100. Clim Res

Illy P (1973) Etude hydrogéologique de la vallée du fleuve Sénégal: projet hydroagricole de bassin du fleuve Sénégal

Iliffe J (1990) Famine in Zimbabwe, 1890-1960. Mambo Press, Harare

Lamagat JP (1996) Comparaison de trois scenarios de gestion du barrage de Manantali. ORSTOM, Paris

Lazenby J, Sutcliffe J (1994) Transitional control of the river Senegal. In: Kirby C, Wright WR (eds) Integrated river basin development. John Wiley \& Sons, New York, p 503-513

Magistro J (1993) Crossing over: ethnicity and transboundary conflict in the Senegal river valley. Cah d'Etud Afr 130/XXXIII-2:201-232

Magistro J (1994) Ecology and production in the middle Senegal valley wetlands. $\mathrm{PhD}$ thesis, Binghamton University, NY

Magistro J (1995) Food insecurity and rice market reform in the Senegal river valley. Paper prepared for the 94th annual meeting of the American Anthropological Association, November 17, 1995, Washington, DC

Michel P (1985) Sécheresse et transformation de la morphodynamique dans la vallée et le delta du Sénégal. Rev Geomorphol Dyn 4:113-130

Niasse M (1990) Village irrigated perimeters at Dougma Rindiaw, Senegal. Dev Anthropol Net 8(1):6-11

Nicholson S (1979) The methodology of historical climate reconstruction and its application to Africa. J Afr Hist 20(1):31-49

Nicholson S (1989) African drought: characteristics, causal theories and global teleconnections. In: Berger A, Dickinson RE, Kidson JW (eds) Understanding climate change. American Geophysical Union, Washington, DC, p 79-100

Nicholson S (1993) An overview of African rainfall fluctuations of the last decade. J Clim 6:1463-1466

Nicholson S (1997) An analysis of the ENSO signal in the tropical Atlantic and western Indian oceans. Intl J Climatol 17:345-375

Nicholson SE, Flohn H (1980) African environmental and climatic changes and the general atmospheric circulation in late Pleistocene and Holocene. Clim Change 2:313-348

Nicholson SE, Kim J (1997) The relationship of the El NiñoSouthern Oscillation to African rainfall. Int J Climatol 17: 117-135

Nicholson S, Palao I (1993) A re-evaluation of rainfall variability in the Sahel. Part I. Characteristics of rainfall fluctuations. Int J Climatol 13:371-389

Nicholson SE, Kim J, Ba MB, Lare AR (1997) The mean sur- 
face water balance over Africa and its interannual variability. J Clim 10:2981-3002

Nicholson SE, Tucker CJ, Ba MB (1998) Desertification, drought, and surface vegetation: an example from the West African Sahel. Bull Am Meteorol Soc 79:815-829

OMVS/Dames and Moore International (1989) Senegal River Upper Valley Master Plan preliminary report-Phase I (policy and planning development project 625-0621). OMVS/USAID, Dakar

OMVS/International Science and Technology Institute (1990) Hydrogeological synthesis report: Senegal River delta, OMVS/USAID Project 625-0958 groundwater monitoring project final report. Vol II. OMVS, Dakar

OMVS/ORSTOM (1997) Etudes de l'optimisation de la gestion des aménagements de l'OMVS: crue 1997, addendum. Dakar: mission de cooperation et d'action culturelle, république française. OMVS, Dakar, ORSTOM, Paris

Raynor S, Malone E (eds) (1998) Human choice and climate change. Batelle Press

Ribot JC, Magalhaes AR, Panagides SS (eds) (1996) Climate variability, climate change and social vulnerability in the semi-arid tropics. Cambridge University Press, Cambridge

Ropelewski CF, Halpert MS (1987) Global and regional scale precipitation and temperature patterns associated with El Nino/Southern Oscillation. Mon Weather Rev 115: 1606-1626

Ropelewski CF, Halpert MS (1989) Precipitation patterns associated with the high index phase of the southern oscillation. J Clim 2:268-284

Rowell DP, Folland CK, Maskell K, Ward NM (1995) Variability of summer rainfall over tropical North Africa (1906-92): observations and modelling. Q J R Meteorol Soc 121:669-704

Semazzi FH, Mehta V, Sud YC (1988) An investigation of the relationship between sub-saharan rainfall and global sea surface temperatures. Atmos Ocean 26:118-138

Sir Alexander Gibb and Partners, Electricité de France International, and EUROCONSULT (1987) Study of the management of the OMVS common works: summary reports. OMVS, Dakar

Sircoulon J (1990) Impact possible des changements clima-

Submitted: February 1, 2000; Accepted: December 11, 2000 tiques a venir sur les ressources en eau des régions arides et semi-arides. World Climate Programme, WCAP-12, WMO/TD No. 380

Smit B, McNabb D, Smithers J (1996) Agricultural adaptation to climatic variation. Clim Change 33:7-29

Smithers J, Smit B (1997) Human adaptation to climate variability and change. Global Environ Change 7(2):129-146

Stern PC, Young OR, Druckman D (eds) (1992) Global environmental change: understanding the human dimensions. National Academy Press, Washington, DC

Tardif-Douglin D, Metzel J, Randolph T (1998) Senegal rice policy reform program: third and final situation report. RSAP/APAP report no. 16. UPA/APAP III, Dakar

Van Lavieren B, Van Wetten J (1990) Profil de l'environnement de la vallée du fleuve Sénégal. Euroconsult / RIN (Institut National de Recherche pour la Conservation de la Nature), Arnhem

Venema HD, Schiller EJ, Adamowski K, Thizy JM (1997) A water resources planning response to climate change in the Senegal river basin. J Environ Manage 49:125-155

Weigel JY (1982) Migration et production domestique des soninké du Sénégal. Travaux et Documents de l'ORSTOM no. 146. ORSTOM, Paris

Wolter K (1989) Modes of tropical circulation, southern oscillation, and Sahel rainfall anomalies. J Clim 2:149-172

Woodhouse P, Ndiaye I (1990) Structural adjustment and irrigated food farming in Africa: the 'disengagement' of the state in the Senegal river valley. Open University, DPP Working Paper No. 20, Open University, DPP (Development Policy and Practice) Research Group, Technology Faculty, Milton Keynes

World Bank (1997) Staff appraisal report: regional hydropower development project (Mali-Mauritania-Senegal). Report no. 16083-AFR. Infrastructure/Water, Urban Development and Energy/Africa Region. World Bank, Washington, DC

World Resources Institute, United Nations Environment Programme, United Nations Development Programme, World Bank (1998) World resources 1998-99: a guide to the global environment. Environmental change and human health. Oxford University Press, New York

Proofs received from author(s): September 27, 2001 